\title{
Intake, rumen fermentation and apparent digestibility of Aerbasi cashmere goats fed corn stover, caragana and their mixture on the Mongolian plateau
}

\author{
Wei Wang \\ Inner Mongolia Agricultural University \\ Tianrong Zhou \\ Inner Mongolia Agricultural University \\ Yushan Jia \\ Inner Mongolia Agricultural University \\ Suri $\mathrm{Na}$ \\ Inner Mongolia Agricultural University \\ Yimin Cai \\ Inner Mongolia Agricultural University \\ Gentu Ge ( $\sim$ gegentu@163.com ) \\ Inner Mongolia Agricultural University
}

Research article

Keywords: Caragana, Corn stover, Digestibility, Goat, Rumen fermentation

Posted Date: December 23rd, 2019

DOI: https://doi.org/10.21203/rs.2.19482/v1

License: (a) (i) This work is licensed under a Creative Commons Attribution 4.0 International License.

Read Full License 


\section{Abstract}

Background To effectively use local available feed resources to address the problem of animal feed shortage in winter, the intake, rumen fermentation and apparent digestibility of Aerbasi cashmere goats fed corn stover (CS), caragana (CA) and their mixture were studied on Mongolian plateau.

Results Sixty healthy Aerbasi cashmere goats (BW $30 \pm 2.35 \mathrm{~kg}$ ) were used in this experiment and the diet were assigned randomly to one of 5 groups (12 sheep/group) in a completely randomized design. The basal diets contain same ratio of concentrate and premix, but different mixing ratio of dry CS and CA. The treatments were designed as CS, CA, CS $80 \%+$ CA 20\% (MT1), CS 50\% + CA 50\% (MT2), and CS 20\% + CA 80\% (MT3). Statistical analyses of chemical composition, intake, apparent digestibility, particle size distribution and fermentation were performed by one-way ANOVA using the general linear model (GLM) procedure of SAS version 9.1. With an increased mixing ratio of CA, intake of DM, NDF, and half cellulose was decreased $(P<0.05)$. Meanwhile intake of $C P, A D F$, and acid detergent lignin $(A D L)$ was increased $(P$ $<0.05$ ). The apparent digestibility of DM, organic matter (OM), and NDF in the CS treatment was higher ( $P$ $<0.05)$ than in the other treatments. Compared to the CS treatment, the proportion of particles $\leq 0.1 \mathrm{~mm}$ in size was significantly $(P<0.05)$ higher in the $C A$ treatment, but this was not the case for particles $>5.0$ $\mathrm{mm}$. With an increased mixing ratio of $C A$, the proportions of $0.5-1.0$ and $1.0-5.0 \mathrm{~mm}$ particles decreased $(P<0.05)$, but the proportion of $>5.0 \mathrm{~mm}$ particles did not. Meanwhile, the proportions of $\leq$ 0.1 and $0.1-0.5 \mathrm{~mm}$ particles increased $(P<0.05)$.

Conclusion The results confirm that caragana and corn stover can be used as animal feed and their mix ration of 4 to 1 has a good mix ratio for goat feed, based on the DM intake, apparent digestibility and VFA contents, and proportion of particles $>1.0 \mathrm{~mm}$ in size.

\section{Background}

The Inner Mongolian plateau, located in North China, has an average altitude of $>1,000 \mathrm{~m}$ [1], and is as one of the highest areas in China with a low winter temperature [2]. The dry continental climate is characterised by an annual rainfall of approximately 8 inches $(200 \mathrm{~mm})$ and the mean temperatures during the warmest and coldest months vary over an enormous range [3]. Traditionally, the people living in the Inner Mongolian plateau region were nomadic and principally engaged in raising sheep and goats; however, extensive livestock farms were developed in the 20th century [4]. Although the harsh climate restricts the agricultural and animal industry, in irrigated areas, corn and other crops can be grown on the plateau.

The major constraint on raising dairy on the plateau is poor livestock feed quality and quantity, especially during the winter season. The main feed resources for goats are hay, made from native grasses, and byproducts from agriculture. Animals fed on low-quality roughage show low production; this is a problem for both the livestock industry and the local economy. In general, cashmere goats feed extensively during the summer, showing relative fatness and thinness during the autumn and winter, respectively, and 
physical weakness during the spring [5]. To improve the livestock production system, to cover the animal feed shortage during the winter season, technologies exploiting locally available resources have been developed. These include determining the adaptability of crop residues and legume shrubs to various conditions, and exploring their nutritional value and potential productivity [6].

Corn (Zea mays L.) stover (CS) is a locally available crop by-product that is widely used for cattle, sheep, and goat feed, at a lower cost than traditional animal feed [7]. When corn is harvested for grain, $40-50 \%$ of the dry matter (DM) of the corn plant remains in the field, including the leaves, stalks, husks, and cobs. After field exposure, the dry stover are collected and preserved for use as roughage for livestock. The use of CS as an animal feed has proven to be economically viable, not only as a way of disposing of CS residues but also as an alternative for feeding livestock in regions where corn is the main crop [8]. At present, CS is the major forage crop in goat dietary regimes in China [9], and it has the potential to provide more support to animal production systems than conventional forage crops in areas with high corn production [10].

Caragana (Caragana arborescens Lam.; CA) is a common shrub located in arid and semiarid areas of North China, and widely distributed in Inner Mongolia [11]. Most previous studies on CA were concerned with its biological taxonomy, genetic diversity, and ecological value; very few studies have assessed its potential applications [12]. In recently years, large quantities of CA were planted as forage crops in Inner Mongolia, due to its high DM yield and CP content [13]. Generally, local farms collect and store CA in the autumn, and mix it with CS for livestock feed during the winter. The nutritional value of CA can compensate for any shortage of CS, and their mixture can be used as a uniquely valuable feed.

CS and CA are believed to be important locally available feed sources, which can be preserved to help farmers feed their livestock throughout the winter. In general, fresh CS and silage can be used for animal feed, since they contain appropriate quantities of nutrients. However, due to a scarcity of winter feed, large amounts of dry CS or CA are currently being fed to sheep and goats in local farms on the Inner Mongolian plateau. When the CS is exposed in the field for a long period, it results in low-quality yields with decreased CP content and poor digestibility. In pastoral areas of grassland, there is a shortage of pasture resources [12,14]. Therefore, it is particularly important to feed cashmere goats at this location. The energy value of the feed directly affects the digestion of nutrients by the animals [15]. In particular, protein energy is a measure of diet quality [16]. Caragana is abundant on the Inner Mongolian plateau and has a high CP content, which is an important indicator of its nutritional status. Local cashmere goats are not productive during the winter, a season in which local farmers can only use dry CS to meet the basic energy requirements of cashmere goats. To improve the nutrient content of $\mathrm{CS}$, local farmers collect $\mathrm{CA}$ in the late autumn, and then mix it with CS as a feed supply for livestock during the winter. In general, the feed mixing ratios used by farms are as follows: CS $80 \%+$ CA $20 \%$, CS $50 \%+$ CA $50 \%$, and CS $20 \%+$ CA $80 \%$. As such, the same ratios were used in this study.

However, to our knowledge, limited information is available on the optimal ratio of CA to CS for promoting growth of goats during the winter. Therefore, the objective of this research is to determine the optimum 
CS:CA ratio for promoting sheep and goat production in the Inner Mongolian plateau, by adding CA to CS in varying proportions. Further objectives were to determine the effects of the feed on the intake amounts, rumen fermentation, and apparent digestibility of Aerbasi cashmere goats.

\section{Results}

The chemical compositions of CS, CA, and their mixture were assessed in Table 1. The DM contents of CS and CA were $91.19 \%$ and $93.05 \%$, respectively, and that of CA was significantly $(P<0.05)$ higher. The organic matter $(\mathrm{OM})$ content of $\mathrm{CA}$ was higher $(P<0.05)$ than that of $\mathrm{CS}, \mathrm{M} 1, \mathrm{M} 2$ and $\mathrm{M} 3$. The crude protein (CP) contents of CS and CA were $4.00 \%$ and $10.62 \%$, respectively. With an increased CA ratio, the $\mathrm{CP}$ content significantly $(P<0.05)$ increased. When comparing CS to CA, the neutral detergent fibre (NDF), hemicellulose $(\mathrm{HC})$, and cellulose $(\mathrm{CEL})$ contents of CS were significantly $(P<0.05)$ higher, and the acid detergent fibre (ADF) and acid detergent lignin (ADL) contents were significantly $(P<0.05)$ lower.

The ingredients and chemical compositions of the diets were assessed in Table 2. According to the winter feeding methods used in the Mongolian Plateau, basal diets were prepared using CS, CA, corn meal, sunflower cake, soybean cake, flaxseed cake, calcium bicarbonate, salt, and mineral-vitamin premix (Inner Mongolia Zheng Da, Hohhot, China). The corn stover treatment (CST), caragana treatment (CAT), MT1, MT2 and MT3 diets contained 4.77-10.95\% CP, 68.11-71.89\% NDF, 47.05-57.89\% ADF, and 10.73$11.82 \mathrm{MJ} \mathrm{kg}^{-1} \mathrm{DM}$ of digestible energy (DE), as estimated in a previous analysis (NRC 2007). Food and water were freely available to the animals. The five diets were formulated to meet the animals' winter energy, protein, mineral, and vitamin requirements based on the Cornell-Penn-Miner guidelines (Inner Mongolia Zheng Da, Hohhot, China). The CST was insufficient in isolation, but the other diets met the nutritional requirements of Mongolian sheep (Salah et al. 2014). According to the ratio of CA to CST, the CP content of MT1 ( $6.37 \%$ of DM) was higher than that of CST ( $4.77 \%$ of DM), but lower than that of CAT (10.95\% of DM), MT2 (7.42\% of DM), and MT3 (8.05\% of DM).

The intake and apparent digestibility of Aerbasi cashmere goats fed CS, CA and their mixture were analysed in Table 3. The DM intake of CS was higher $(P<0.05)$, and that of CA lower, $(P<0.05)$ versus the MT1, MT2 and MT3 treatments. With an increased CA mixing ratio, the intake amounts of OM, CP, ADF, and ADL contents were significantly $(P<0.05)$ increased, while the NDF and $\mathrm{HC}$ intakes were significantly $(P<0.05)$ decreased. The apparent digestibility of DM, OM, NDF, and HC in CS was higher $(P<0.05)$ than in the CA, MT1, MT2 and MT3 treatments. The DM intake of CS was significantly higher $(P<0.05)$ than that of CA. The DM intake for MT1 was not significantly higher ( $P>0.05)$ than those for MT2 while it was significantly higher $(P<0.05)$ than MT3, while the apparent digestibility of DM in MT1 was significantly higher $(P<0.05)$ than in MT2 and MT3.

The volatile fatty acid (VFA) contents in the rumen of Aerbasi cashmere goats fed CS, CA, and a mixture were analysed in Table 4. The ruminal pH of goats fed CS was significantly $(P<0.05)$ lower than that of those fed CA. The ammonia content in CA was the highest, and the ammonia content of MT1 was significantly higher $(P<0.05)$ than that in CS. Total VFA content in MT1 was significantly increased 
$(P<0.05)$ compared to MT2 and MT3. With increased mixing ratio of CA, the acetic acid (AA), propionic acid (PA), butyric acid, and total VFA contents, and AA/PA ratio, significantly $(P<0.05)$ decreased, and the content of AA,PA,BA in MT1 was higher than MT2 and MT3 $(P<0.05)$; however, the ammonia content was significantly $(P<0.05)$ reduced initially, and then increased.

The particle size distribution of rumen in Aerbasi cashmere goats fed CS, CA, and a mixture were analysed in Table 5. The $0.5 \mathrm{~mm}$-sized particles had the highest relative abundance among all particle sizes in all treatments, at $>32 \%$; the $5.0 \mathrm{~mm}$-sized particles had the lowest relative abundance, of $\leq 1 \%$. Compared to the CS treatment, the $\leq 0.1 \mathrm{~mm}$-sized particles were significantly $(P<0.05)$ more abundant in $\mathrm{CA}$, but the abundance of the $>5.0 \mathrm{~mm}$-sized particles did not differ. With increased mixing ratio of CA, the proportions of the $0.5-1.0,1.0-5.0$ and $>5.0 \mathrm{~mm}$ particles decreased $(P<0.05)$, and those of the $\leq$ 0.1 and $0.1-0.5 \mathrm{~mm}$ particles increased $(P<0.05)$. The proportion of $>1.0 \mathrm{~mm}$-sized particles (including $1.0-5.0$ and $>5.0 \mathrm{~mm})$ in MT1 $(11.96 \%)$ was higher $(P<0.05)$ than in MT2 $(8.45 \%)$ and MT3 $(5.57 \%)$.

\section{Discussion}

Compared to CS, the CP content of CA was higher by $6 \%$, and its NDF was lower by $4 \%$. Therefore, with increased mixing ratio of $\mathrm{CA}$, the $\mathrm{CP}$ content of the mixtures increased and the NDF content decreased. Since woody plants have high lignin content [17], the ADF and ADL contents of CA were higher than those of CS or their mixture. The MT1 in this study was close to meeting the CP requirement of goats [18]; when $20 \%$ of CA was added to the CS, the CP content increased and the nutritional requirements were met to the goats.

Five diets were formulated to meet the animals' mineral and vitamin requirements based on the CornellPenn-Miner recommendations [9]. It showed the MT1 was 6.37\% DM which can meet the CP requirements (5.1\% DM) of cashmere goats during the winter, and we can assess its utility as feed. As shown in Table 2 , these diets were formulated as a general winter feed, but the energy and protein contents were insufficient to meet the nutritional requirements of the Mongolian sheep [4].

General, woody plants contain large amounts of ADF and ADL, which results in decreased nutrient uptake and digestibility for livestock [19-20]. In the present study, the ADF and ADL contents of CA were higher than those of CS [6]. In addition, with increased mixing ratio of CA, the DM intake decreased. The major reason for this is that that $\mathrm{CA}$ has higher fibre and lignin content, which results in reduced dietary energy, feed uptake, and digestibility. If the ADF and ADL content in the diet was increased, and the goats had full rumens, continuous feed intake would be inhibited [21]. The high fibre content could influence digestibility and cause the goats to feel more full, and therefore reduce their intake [9]. The lignin content of CA, and its effect on the production performance of goats, is a major factor limiting its use in feed mixtures [2223].

The apparent digestibility of DM in MT2 and MT3 was lower than that in MT1, showing that the MT1 was a good mixing ratio which has a higher apparent digestibility of DM. When the mixing ratio of CA was over $20 \%$, the high lignin resulted in low apparent digestibility of DM. Regarding production, the apparent 
digestibility of $\mathrm{CP}$ increases with an increase of dietary CP. This could be due to reasonable dietary protein levels being conducive to the reproduction of rumen microbes, enhancing the ability to break down fibres, and thereby increasing their digestion and absorption [4,24]. Additionally, CA contains various vitamins, trace elements, fats, sugars, nucleic acids, and inorganic nutrients, such as potassium, calcium, and magnesium, all of which are conducive to the growth and reproduction of fibredecomposing bacteria [25]. Generally, the activity of rumen microorganisms may be low when ruminant fed low CP feed. As a result, it is difficult to correctly evaluate the difference in digestibility and rumen fermentation. In the future, it is necessary to study the relationship between low CP content and rumen microorganism activity, digestibility or rumen fermentation.

The proportions of various sizes of pellets in sheep rumen and faeces were assessed. Small particles were most abundant, with those $<3 \mathrm{~mm}$ in size accounting for $>90 \%$ of all particles for both CA and CS. There was no significant difference in particle size distribution among the different types of roughage ( $P>$ 0.05). The proportion of $>1.0 \mathrm{~mm}$-sized particles in MT1 (11.96\%) was higher than those in MT2 and MT3. The small-sized particles $(0.1-1 \mathrm{~mm})$ were most abundant in MT3 relative to the other treatments, while the large particles $(1-5 \mathrm{~mm})$ were most abundant in CS. The reason for this may be related to the lignin in the diet, the lower ADL content in MT1 affects digestible particle activities and nutrient digestion [16,26-27]. The ADL content in MT3 (22.82\% of DM) was lower than that in CA (24.72\% of DM), but higher than in the other treatments. Due to the difficulty in digesting ADL, it stayed in the rumen for a long period [28]. Particles are chewed by cashmere goats repeatedly, such that the number of particles and surface area of the cell walls are increased, in turn increasing the chance that bacteria can reach the fibre and colonise it [29]. There were no significant effects of particle size on the $\mathrm{pH}$ of the gastrointestinal tract at the time of slaughter. Previous studies reported no effect of corn particle size on rumen $\mathrm{pH}$, and that starch content varying from $28 \%$ to $46 \%$ does not affect $\mathrm{pH}$ [30].

Similarly, in the present study, differences in particle size did not greatly influence $\mathrm{pH}$ [31]. A higher proportion of $1.0 \mathrm{~mm}$-sized particles indicates that the indigestible and degradable content of feed is higher [22,32]. Here we found the MT1 contained a higher proportion of $>1.0 \mathrm{~mm}$-sized particles, which explains why the goats were able to refine the feed pellets via multiple ruminations and chewing, to increase the availability of surface microorganisms [33]. Therefore, adding $20 \%$ CA was effective for improving feed digestibility.

Typically, grazing is prohibited from mid-March to mid-June, but it remains necessary to supply cashmere goats with proper nutrition at a low cost. Cashmere goats are most productive from the beginning of September to the end of December, and their productivity ceases in February. In this study, we were able to supply nutrients at, or slightly below, the level required to maintain the goats. Cashmere goats have a greater ability to digest high-fibre materials than do sheep [10,34]. Our data showed that, even though the CA cannot meet the nutritional needs of cashmere goats, increasing the ratio of CA to CS is feasible for feeding cashmere goats. In the future, a longer-term experiment is needed to study changes in digestive metabolism, carcass health status, and production performance after long-term feeding of livestock with unconventional feed in the Inner Mongolian Plateau desert grassland. 


\section{Conclusion}

The intake, rumen fermentation, and apparent digestibility of Aerbasi cashmere goats fed CS, CA, and a mixture of the two were studied in the Inner Mongolia plateau. With increased CA mixing ratio, the CP dietary content, intake amounts, and apparent digestibility of CP increased. The intake and apparent digestibility of DM, rumen ammonia, and VFA, and the proportion of $>1.0 \mathrm{~mm}$-sized particles, were higher in MT1 than in MT2 and MT3, indicating that MT1 was a good option as goat feed.

\section{Methods}

\section{Animal care}

The source of the animals used in experiments were acquired by the Committee of Animal Experimentation and were performed under the institutional guidelines for animal experiments of the College of Animal Science, Inner Mongolian Agricultural University, China. The experiment was performed according to recommendations proposed by the European Commission (1997) to minimize the suffering of animals.After the experimental procedure, the experimental sheep will not be killed, and they will continue to provide help for the future research work and provide suitable living conditions for them in the future life.

\section{Diet and experimental design}

The CS and CA were both harvested from an Agricultural Field of Xiwuzhumuqin town, Xilinhot, China. We had permission to use this field for our study, and all experiments were conducted in accordance with local legislation.The CS at maturity stage was obtained at $5 \mathrm{~d}$ of field exposure after corn harvest, and the stovers were chopped into approximately $2 \mathrm{~cm}$ by a chopper (TS420; Qufu Machinery Equipment Co., Ltd., China). The CA at growth stage was obtained after $7 \mathrm{~d}$ of harvest, and the small branches and leaves were crushed to $4 \mathrm{~mm}$ with a crusher (FW100, Guangming Machine Co., Ltd, Beijing, China). The mixing ratio and chemical composition of CS and CA are shown in Table 1.

Based on the feeding methods used on the Mongolian Plateau, the diets in this study were prepared from CS, CA, corn meal, sunflower cake, soybean cake, flaxseed cake, calcium bicarbonate, salt, and mineralvitamin premix (Inner Mongolia Zheng Da, Hohhot, China). The treatment diets contained similar concentrate mixtures and fine feed, but different pro-portions of CS and CA. The treatments were (1) corn stover (CS); (2) caragana (CA); (3) CS 80\% + CA 20\% (MT 1); (4) CS 50\% + CA 50\% (MT 2); (5) CS 20\% + CA $80 \%$ (MT 3). The ration ingredient composition is shown in Table 2. The Table 2 contained the corn stover treatment (CST), caragana treatment(CAT), MT1, MT2 and MT3. The roughage in the diet consisted of $20.66-82.64 \%$ CS on a DM basis, while the concentrate consisted of $9.97 \%$ corn grain, $0.99 \%$ sunflower cake, $1.66 \%$ Soybean cake, and $3.30 \%$ Flaxseed cake. The diet contained calcium bicarbonate, vitamin premix and mineral premix. The Mineral-vitamin premix composition were $2.4 \times 10^{4}$ $\mathrm{mg} / \mathrm{kg} \mathrm{Fe} ; 7 \times 10^{3} \mathrm{mg} / \mathrm{kg} \mathrm{Cu}, 3 \times 10^{4} \mathrm{mg} / \mathrm{kg} Z \mathrm{n} ; 1.25 \times 10^{4} \mathrm{mg} / \mathrm{kg} \mathrm{Mn} ; 30 \mathrm{mg} / \mathrm{kg} \mathrm{l,} 850 \mathrm{mg} / \mathrm{kg} \mathrm{Co}, 5 \times 10^{8}$ 
$\mathrm{IU} / \mathrm{kg}$ Vitamin $A$ and Vitamin $\mathrm{D}_{3}, 1 \times 10^{8} \mathrm{IU} / \mathrm{kg}$. The diet was formulated to meet the nutritional requirements of Mongolian sheep [35]. Five diets were formulated to meet the animals' requirements for energy, protein, minerals, and vitamins based on Cornell-Penn-Miner [9]

\section{Growth trial}

Sixty healthy Aerbasi cashmere goats (BW $=30 \pm 2.35 \mathrm{~kg}$; mean $\pm \mathrm{SD}$ ) were used in a randomly experiment. Groups were balanced for parity and production during each period. The diet were assigned randomly to one of 5 groups (12 sheep/group) in a completely randomized design. They were penned individually in a well-ventilated shed that was cleaned weekly. Before starting the trial, all goats were vaccinated against clostridial diseases and treated for internal parasites. The diet was provided with an allowable refusal level of $10 \% \mathrm{DM}$ of the diet. The animals were fed the diets three times a day at 8:00, 13:00 and 19:00, and clean drinking water was available at all times. After a 10 days adaptation period, the 45 days growth trial was started. Feed offered and feed residues were weighed daily along the growth trial to calculate the net intake of feed. The refused feed was collected daily, weighed, and individually bulked for analysis. Samples of the daily refusals from each animal and feed offered were dried at $105^{\circ} \mathrm{C}$ for 24 hours to determine the DM intake.

\section{Digestibility trial}

When the growth trial experiment was completed, the apparent nutrient digestibility of the experimental diets was taken in animals in metabolic cages equipped with separate feeders, an automatic watering trough, and a system for the separate collection of feces and urine. Twelve goats ( $30 \pm 2.35 \mathrm{~kg})$ in each treatment were selected for the digestibility trial. The experiment consisted of 14 days of adaptation to the diet in individual stalls with a concrete floor, 2 days of adaptation to the fecal collection bags, and 5 days of feces collection [36-37]. The bags $\left(25 \mathrm{~cm}^{2}\right)$ were made of nonwoven textile $\left(100 \mathrm{~g} / \mathrm{m}^{2}\right)$ material and a sample weight to bag surface area ratio of $20 \mathrm{mg} \mathrm{DM} / \mathrm{cm}^{2}$ was used [38]. Offered and refused food were recorded daily and composite samples, pooled on an individual animal basis at the end of each collection period, were dried at $105^{\circ} \mathrm{C}$ for 24 hours to determine the DM intake. Another sample of the diet was ground in a hammer mill with a 1-mm screen and stored until analysis. Feces were collected daily and weighed and $20 \%$ of the total daily excretion was dried at $70^{\circ} \mathrm{C}$ for 48 hours and pooled on an individual animal basis at the end of the collection period. The daily spot urinary samples were collected for $2 \mathrm{~h}$ with bowls attached with a harness to each animal $4 \mathrm{~h}$ after the morning feeding. Ten $\mathrm{ml}$ urine sample was diluted with $40 \mathrm{ml}$ of a $0.036 \mathrm{~N} \mathrm{H}_{2} \mathrm{SO}_{4}$ solution and stored at $-20^{\circ} \mathrm{C}$ for later analysis.

\section{Chemical analysis}

The feedstuff was recorded every day and it was weighed for 3 consecutive days to determine the dry matter intake (DMI), organic matter intake (OMI), crude protein intake (CPI), neutral detergent fiber intake 
(NDFI), acid detergent fiber intake (ADFI), acid detergent lignin intake (ADLI), half cellulose intake ( $\mathrm{HCl})$ and cellulose intake (CELI). The particle size of feedstuff was sampled by utilizing the Penn State Particle Separator as described [39]. Apparent nutrient digestibility was calculated utilizing indigestible nutrition (12-d ruminal incubation in 25- $\mu \mathrm{m}$-pore-size bags) as an internal marker, based on the concentration of indigestible nutrition in the diet. The $\mathrm{pH}$ was measured with a glass electrode $\mathrm{pH}$ meter (STARTER 100/B, OHAUS, Shanghai, China), the ammonia-N content was analyzed by using steam distillation of the filtrates 23 , the concentration of organic acid were measured by high performance liquid chromatography methods as described [40].

Sample of feedstuff were dried for $48 \mathrm{~h}$ at $65^{\circ} \mathrm{C}$ in a forced-air oven and ground to pass through a 1-mm screen in a Wiley mill before analysis[4]. The contents of organic matter (OM), crude protein (CP), neutral detergent fiber (NDF), acid detergent fiber (ADF), acid detergent lignin (ADL), half cellulose (HC) and cellulose (CEL) were tested in accordance with the reference of the AOAC International [41]. The content of NDF, ADF, ADL, HC and CEL were analyzed according to the Ankom A200 fiber analyzer (Ankom Technology, Macedon, NY) by the method of Van Soest [42].

\section{Statistical analysis}

Statistical analyses of chemical composition, intake, apparent digestibility, particle size distribution and fermentation were performed by one-way analysis of variance of SAS (SAS 9.0, SAS Inc. Chicago, USA) and the statistical model is: $Y_{i j}=\mu+T_{i}+E_{i j}$, where $Y_{i j}$ is observation for dependent variables, $\mu$ is overall mean, $T_{i}$ is effect of treatment, and $E_{i j}$ is residual error. Statistical difference among means were tested by least significant difference multiple comparison[43]. Polynomial contrasts were used to test linear, quadratic and cubic responses to CS and CA mixture ratios. The significant difference was declared at $P$ $<0.05$.

\section{Abbreviations}

DM, dry matter;

$\mathrm{OM}$, organic matter;

$\mathrm{CP}$, crude protein;

NDF, neutral detergent fiber;

ADF, acid detergent fiber;

$A D L$, acid detergent lignin;

$\mathrm{HC}$, half cellulose;

CEL, cellulose. 
DE: diet energy

VFA, volatile fatty acid;

AA/PA, ratio of acetic acid to propionic acid.

\section{Declarations}

\section{Overview}

All authors have read and agreed to the content of the paper, which meets the submission requirements for BMC Veterinary Research.

\section{Ethics and consent}

The experiments goats were allowed to the local animal protection law, and there was no IRB review committee (institutions) or IACUC (institutional animal care and use committee) at local area, but we gain the technical support from the professors from Inner Mongolia agricultural university college of animal science. In addition, the experimental sheep will be well placed in the animal placement center of the west campus of Inner Mongolia agricultural university (located at 306 zhaowuda road, saihan district, Hohhot, Inner Mongolia) after the end of the experiment. During the later management period, sufficient feed will be ensured for the experimental sheep.

\section{Research involving animals}

The experiments goats were allowed to the local animal protection law, and there was no IRB review committee (institutions) or IACUC (institutional animal care and use committee) at local area, but we gain the technical support from the professors from Inner Mongolia agricultural university college of animal science. In addition, the experimental sheep will be well placed in the animal placement center of the west campus of Inner Mongolia agricultural university (located at 306 zhaowuda road, saihan district, Hohhot, Inner Mongolia) after the end of the experiment. During the later management period, sufficient feed will be ensured for the experimental sheep.

\section{Biosafety and Biosecurity}

Not applicable

\section{Standards for research in complementary and alternative medicine}

Not applicable

\section{Consent to publish}

Not applicable 


\section{Trial registration}

Not applicable

\section{Availability of data and materials}

All data generated or analyzed during this study are included in this published article and its supplementary information files.

\section{Standards of reporting}

Not applicable

\section{Competing Interest}

The authors declare that they have no conflicts of interest to disclose.

\section{Authorship}

WW, GGT,YMC and YSJ designed the experiments; WW and TRZ conducted the experiments; WW, NRS and QY analyzed the data; WW and TRZ wrote the paper. All authors read and approved the final manuscript.

\section{Citations}

1. Tong SQ, Zhang JQ, Bao YH. Inter-decadal Spatiotemporal Variations of Aridity Based on Temperature and Precipitation in Inner Mongolia, China. Pol J Environ Stud 2017; 26:819-26.

2. Dai SC, Wang CX, Wang ZY. Inbreeding and its effects on fleece traits of Inner Mongolia cashmere goats. Small Ruminant Res 2015; 128:50-3.

3. Zhao YW, Hong H, Jin HG. Appropriate feed-in tariff of solar-coal hybrid power plant for China's Inner Mongolia Region. Appl Therm Eng 2016; 108:378-87.

4. Xu M, Yao JH, Wang YH,Wang FN. Influence of rumen escape starch on a-amylase activity in pancreatic tissue and small intestinal digesta of lambs. Asian Austral J Anim 2006; 19: 1749-54.

5. Dong QM, Zhao XQ, Ma YS, et al. Live-weight gain, apparent digestibility, and economic benefits of yaks fed different diets during winter on the Tibetan plateau. Livest Sci 2006; 101:199-207.

6. Malhado CHM, Malhado ACM, Carneiro PLS, et al. Inbreeding depression on production and reproduction traits of buffaloes from Brazil. J Anim Sci 2013; 84:289-295.

7. Yuan XJ, Yu CQ, Li ZH, et al. Effect of inclusion of grasses and wet hulless barley distillers' grains on the fermentation and nutritive quality of oat straw and straw-grass silages in Tibet. J Anim Produc Sci 2013; 53:419-26.

8. Lesmeister KE, Heinrichs AJ. Effects of corn processing on growth characteristics, rumen development, and rumen parameters in neonatal dairy calves. J Dairy Sci; 2004; 87:3439-50. 
9. Xu M, Dong Y, Du S, et al. Effect of corn particle size on mucosal morphology and digest $\mathrm{pH}$ of the gastrointestinal tract in growing goats. Livest Sci 2009; 123:34-7

10. Shen ZM, Seyfert HM, Löhrke B, et al. An energy-rich diet causes rumen papillae proliferation associatedwith more IGF type 1 receptors and increased plasma IGF-1 concentrations in young goats. J Nutr 2004; 134:11-7.

11. Zhong C, Wang R, Zhou Z, et al. Functional properties of protein isolates from Caragana korshinskii Kom. extracted by three different methods. J Agric Food Chem 2016; 60:10337-42.

12. Ma CC, Gao YB, Guo HY. Physiological adaptation of four dominant Caragana species in the desert region of the Inner Mongolia Plateau. J Arid Environ 2008; 27:247-54.

13. Zhong C, Sun Z, Zhou Z, et al. Chemical Characterization and Nutritional Analysis of Protein Isolates from Caragana korshinskii Kom. J Agric Food Chem 2014; 62:3217-22.

14. Long RJ, Apori SO, Castro FB, et al. Feed value of native forages of the Tibetan Plateau of China. Anim Feed Sci Technol 1999; 80:101- 13.

15. Galyean ML, Wagner DG, Owens FN. Corn particle size and site and extent of digestion by steers. J Anim Sci 1979; 49: 204-210.

16. Janes AN, Weeks TEC, Armstrong DG. Carbohydrase activity in the pancreatic tissue and small intestine mucosa of sheep fed dried-grass or ground maize-based diets. J Agr Sci 1985; 104: 43543.

17. Hacke UG, Sperry JS, Pockman WT, et al. Trends in wood density and structure are linked to prevention of xylem implosion by negative pressure.Oecologia 2001; 126: 457-61.

18. Zhou HM, Allain D, Li JQ. Effects of non-genetic factors on production traits of inner mongolia cashmere goats in China. Small Ruminant Res 2003; 47:85-89.

19. Carlquist $S$, Hoekman DA. Ecological wood anatomy of the woody southern California flora. IAWA Bulletin 1985; 6:319-47.

20. Malisetty V, Yerradoddi RR, Evanaboina N, et al. Effect of feeding sorghum straw based complete rations with different roughage to concentrate ratio on dry matter intake, nutrient utilization, and nitrogen balance in Nellore ram lambs. Trop Anim Health Pro 2014; 46:759-64.

21. Domingue BM, Dellow DW, Barry TN, Voluntary intake and rumen digestion of a low-quality roughage by goats and sheep. J. Agric. Sci 1991; 117:111-20.

22. Zhang GS, Li Y, Fu Y. Silage quality of robinia pseudoacacia, caragana korshinskii and amorpha fruticosa. Journal of Northwest Forestry University 2009; 1:38.

23.Yang X, Niu X, Li J, et al. Nutrient evaluation of caragana korshinskii on cattle. J Yellow Cattle Sci 2005; 4:10.

24. McDonald I. A revised model for the estimation of protein degradability in the rumen. J Agr Sci 1981; 96:251-2. 
25. Salem, H.B. Nutritional management to improve sheep and goat performances in semiarid regions. R. Bras. Zootec. 2010; 39: 337-47

26. Russell JR, Young AW, Jorgensen NA. Effect of dietary corn starch intake on pancreatic amylase and intestinal maltase and $\mathrm{pH}$ in cattle. J Anim Sci 1981; 52: 1177-82.

27. Grant RJ, Weidner SJ. Digestion kinetics of fiber: influence of in vitro buffer $\mathrm{pH}$ varied within observed physiological range. J Dairy Sci 1992; 75:1060-8.

28. Kornfelt LF, Weisbjerg MR, Nørgaard P. Effect of harvest time and physical form of lucerne silage on chewing time and particle size distributionin boli, rumen content and faeces. Animal 2013; 7:232-44.

29 .Mudgal, VD., Dixon, RM., Kennedy, PM., Milligan, LP. Effect of two intake levels on retention times of liquid, particle and microbial markers in therumen of sheep. J. Anim. Sci. 54, 1051-5.

30. Traiyakun S, Paengkoum P. Supplementation of Chicory and Jerusalem artichoke in sheep diets on ruminal fermentation and nitrogen retention. J. Anim. Vet. Adv. 2013; 12: 996-9

31.Wang SP, Wang WJ. Effects of dietary supplementation of Chinese herb medicine mixture on rumen fermentation, nutrient digestion and blood profile in goats. South African J Anim Sci 2016; 46:247-60.

32.Polyorach S, Wanapat M, Cherdthong A. Influence of yeast fermented cassava chip protein (yefecap) and roughage to concentrate ratio on ruminal fermentation and microorganisms using in vitro gas production technique. Asian Austral J Anim 2014; 27: 36-45.

33. Hodate K. Analysis method for Vitamins. In: Self-Feed Evaluation Society (ed.), Guidebook for Evaluation of Roughage Quality. Japan Grassland Animal Husbandry Seeds Association, Tokyo, Japan. 2004; p. 18-9.

34. Salah N, Sauvant D, Archimede H. Nutritional requirements of sheep, goats and cattle in warm climates: a meta-analysis. Animal 2014; 8:1439-47.

35. Bhatt RS, Soren NM, Tripathi MK, et al. Effects of different levels of coconut oil supplementation on performance, digestibility, rumen fermentation and carcass traits of Malpura lambs. Anim Feed Sci Technol 2011; 164: 29-37.

36. Aboagye IA, Lynch JP, Church JS, et al. Digestibility and growth performance of sheep fed alfalfa hay treated with fibrolytic enzymes and a ferulic acid esterase producing bacterial additive. Anim Feed Sci Technol 2015; 203: 53-66.

37.Nocek JE. In situ and other methods to estimate ruminal protein and energy digestibility: A review. J Dairy Sci 1988; 71:2051-69.

38. Heinrichs AJ, PJ Kononoff. Evaluating particle size of forages and TMRs using the new Penn State Forage Particle Separator. College of Agr Sci 2002: 3-14.

39. Huston JE. Goat species: Nutrient requirements of goats. J Anim Sci 2007; 85: 387. 
40. Cai Y. Analysis method for silage. In: Japanase Society of Grassland Science (ed.), Field and laboratory methods for grassland science. Tosho Printing Co., Ltd. Tokyo, Japan. 2004. p. 279-82.

41. Horwitz W, Latimer Jr. GW. AOAC International. Official methods of analysis of AOAC International. 18th ed. Gaithersburg, MD: AOAC International. 2005.

42.Van Soest PJ, Robertson JB, Lewis BA. Methods for dietary fiber, neutral detergent fiber, and nonstarch polysaccharides in relation to animal nutrition. J Dairy Sci 1991; 74:3583-97.

43. SAS. SAS user's guide: Statistic Analysis System, Version 9.1. SAS Institute Inc., Cary, NC, USA. 2003

\section{Tables}

Table 1.

Chemical composition (\% DM) of corn stover (CS) and caragana (CA) and their mixture (M)

\begin{tabular}{lccccccc}
\hline & CS & CA & M1 & M2 & M3 & SEM & $P$-value \\
\hline DM (\%) & $91.19 \pm 0.18^{\mathrm{d}}$ & $93.05 \pm 0.32^{\mathrm{a}}$ & $91.38 \pm 0.09^{\mathrm{d}}$ & $92.03 \pm 0.04^{\mathrm{c}}$ & $92.55 \pm 0.22^{\mathrm{b}}$ & 1.50 & 0.002 \\
\hline OM & $92.58 \pm 0.03^{\mathrm{d}}$ & $96.81 \pm 0.17^{\mathrm{a}}$ & $92.97 \pm 0.12^{\mathrm{d}}$ & $93.01 \pm 0.03^{\mathrm{c}}$ & $94.26 \pm 0.01^{\mathrm{b}}$ & 1.42 & $<0.001$ \\
\hline CP & $4.00 \pm 0.27^{\mathrm{e}}$ & $10.62 \pm 0.11^{\mathrm{a}}$ & $6.37 \pm 0.13^{\mathrm{d}}$ & $7.42 \pm 0.12^{\mathrm{c}}$ & $8.05 \pm 0.22^{\mathrm{b}}$ & 0.60 & $<0.001$ \\
\hline NDF & $71.59 \pm 1.14^{\mathrm{a}}$ & $67.89 \pm 1.32^{\mathrm{d}}$ & $70.13 \pm 1.31^{\mathrm{b}}$ & $68.57 \pm 1.23^{\mathrm{c}}$ & $68.14 \pm 1.29^{\mathrm{d}}$ & 0.74 & $<0.001$ \\
\hline ADF & $46.97 \pm 0.82^{\mathrm{e}}$ & $57.42 \pm 0.93^{\mathrm{a}}$ & $49.36 \pm 0.24^{\mathrm{d}}$ & $52.25 \pm 0.12^{\mathrm{c}}$ & $55.33 \pm 0.22^{\mathrm{b}}$ & 1.52 & $<0.001$ \\
\hline ADL & $16.34 \pm 0.03^{\mathrm{e}}$ & $24.72 \pm 0.22^{\mathrm{a}}$ & $18.52 \pm 0.14^{\mathrm{d}}$ & $20.76 \pm 0.08^{\mathrm{c}}$ & $22.82 \pm 0.12^{\mathrm{b}}$ & 1.19 & $<0.001$ \\
\hline HC & $24.62 \pm 0.21^{\mathrm{a}}$ & $10.47 \pm 0.16^{\mathrm{e}}$ & $22.19 \pm 0.14^{\mathrm{b}}$ & $15.88 \pm 0.13^{\mathrm{c}}$ & $13.45 \pm 0.09^{\mathrm{d}}$ & 0.57 & $<0.001$ \\
\hline CEL & $33.59 \pm 0.03^{\mathrm{a}}$ & $31.90 \pm 1.44^{\mathrm{c}}$ & $33.02 \pm 0.31^{\mathrm{a}}$ & $32.37 \pm 0.42^{\mathrm{b}}$ & $32.21 \pm 0.21^{\mathrm{b}}$ & 0.58 & $<0.001$ \\
\hline
\end{tabular}

Data are means of three samples, means \pm SD within same columns with different superscript letters $\operatorname{differ}(P<0.05)$. DM, dry matter; $\mathrm{OM}$, organic matter; $\mathrm{CP}$, crude protein; NDF, neutral detergent fiber; $\mathrm{ADF}$, acid detergent fiber; $\mathrm{ADL}$, acid detergent lignin; $\mathrm{HC}$, half cellulose; $\mathrm{CEL}$, cellulose.

Table 2. Ingredients and chemical composition of diets 


\begin{tabular}{lccccc}
\hline & CST & MT 1 & MT 2 & MT 3 & CAT \\
\hline Ingredients & & & & & \\
CS & $82.64 \pm 1.27$ & $61.98 \pm 1.05$ & $41.32 \pm 0.11$ & $20.66 \pm 0.63$ & 0 \\
CA & 0 & $20.66 \pm 0.04$ & $41.32 \pm 0.11$ & $61.98 \pm 0.63$ & $82.64 \pm 1.27$ \\
Corn meal & $9.97 \pm 0.22$ & $9.97 \pm 0.22$ & $9.97 \pm 0.22$ & $9.97 \pm 0.22$ & $9.97 \pm 0.22$ \\
Sunflower cake & $0.99 \pm 0.04$ & $0.99 \pm 0.04$ & $0.99 \pm 0.04$ & $0.99 \pm 0.04$ & $0.99 \pm 0.04$ \\
Soybean cake & $1.66 \pm 0.29$ & $1.66 \pm 0.29$ & $1.66 \pm 0.29$ & $1.66 \pm 0.29$ & $1.66 \pm 0.29$ \\
Flaxseed cake & $3.30 \pm 0.35$ & $3.30 \pm 0.35$ & $3.30 \pm 0.35$ & $3.30 \pm 0.35$ & $3.30 \pm 0.35$ \\
Calcium bicarbonate & $0.41 \pm 0.18$ & $0.41 \pm 0.18$ & $0.41 \pm 0.18$ & $0.41 \pm 0.18$ & $0.41 \pm 0.18$ \\
Salt & $0.20 \pm 0.27$ & $0.20 \pm 0.27$ & $0.20 \pm 0.27$ & $0.20 \pm 0.27$ & $0.20 \pm 0.27$ \\
Premix & $0.82 \pm 0.31$ & $0.82 \pm 0.31$ & $0.82 \pm 0.31$ & $0.82 \pm 0.31$ & $0.82 \pm 0.31$ \\
Chemical composition & & & & & \\
DM (\%) & $91.76 \pm 0.18$ & $91.66 \pm 1.32$ & $92.12 \pm 0.46$ & $92.59 \pm 0.27$ & $93.63 \pm 0.32$ \\
OM & $93.14 \pm 0.17$ & $93.64 \pm 0.04$ & $94.70 \pm 0.91$ & $95.75 \pm 0.23$ & $97.23 \pm 0.03$ \\
CP & $4.77 \pm 0.27$ & $6.37 \pm 1.05$ & $7.42 \pm 0.66$ & $8.05 \pm 0.37$ & $10.95 \pm 0.11$ \\
NDF & $71.89 \pm 1.14$ & $70.67 \pm 0.94$ & $69.74 \pm 1.31$ & $68.82 \pm 0.33$ & $68.11 \pm 1.32$ \\
ADF & $47.05 \pm 0.82$ & $49.58 \pm 1.73$ & $52.20 \pm 1.27$ & $54.81 \pm 0.49$ & $57.89 \pm 0.93$ \\
DE (MJ kg ${ }^{-1}$ ) & $11.82 \pm 0.03$ & $10.97 \pm 0.02$ & $10.88 \pm 0.01$ & $10.73 \pm 0.04$ & $11.02 \pm 0.02$ \\
\hline & & & & &
\end{tabular}

Data are means of three samples, means \pm SD within same columns with different superscript letters differ $(P<0.05)$. $\mathrm{DM}$, dry matter; OM, organic matter; $\mathrm{CP}$, crude protein; NDF, neutral detergent fiber; $A D F$, acid detergent fiber. DE: diet energy.

Table 3. Intake ( $\mathrm{g} / \mathrm{kg} \mathrm{W}^{0.75}$ ) and apparent digestibility (\% DM) of Aerbasi cashmere goats fed corn stover (CS), caragana (CA) and their mixture (M) 


\begin{tabular}{|c|c|c|c|c|c|c|c|c|c|}
\hline & \multirow[t]{2}{*}{ CS } & \multirow[t]{2}{*}{$\mathrm{CA}$} & \multirow[t]{2}{*}{ MT 1} & \multirow[t]{2}{*}{ MT 2} & \multirow[t]{2}{*}{ MT 3} & \multirow[t]{2}{*}{ SEM } & \multicolumn{3}{|c|}{$P$-value } \\
\hline & & & & & & & Linear & Quadratic & Cubic \\
\hline \multicolumn{10}{|l|}{ Intake } \\
\hline DM & $65.15 \pm 1.34^{a}$ & $62.57 \pm 1.06^{\mathrm{d}}$ & $64.82 \pm 1.22^{\mathrm{b}}$ & $64.29 \pm 1.31^{b}$ & $63.11 \pm 0.84^{\mathrm{C}}$ & 0.68 & 0.557 & $<0.001$ & 0.003 \\
\hline $\mathrm{OM}$ & $60.54 \pm 0.57^{b}$ & $61.81 \pm 0.22^{\mathrm{a}}$ & $60.67 \pm 0.14^{b}$ & $60.94 \pm 0.84^{b}$ & $61.22 \pm 0.29^{a}$ & 0.11 & 0.024 & 0.023 & 0.586 \\
\hline $\mathrm{CP}$ & $3.27 \pm 0.24^{\mathrm{d}}$ & $7.04 \pm 0.11^{\mathrm{a}}$ & $4.18 \pm 0.22^{c}$ & $5.22 \pm 0.06^{b}$ & $5.97 \pm 0.21^{b}$ & 0.56 & 0.282 & 0.327 & 0.020 \\
\hline NDF & $54.59 \pm 0.38^{\mathrm{a}}$ & $45.24 \pm 0.27^{\mathrm{e}}$ & $52.88 \pm 0.15^{\mathrm{b}}$ & $49.36 \pm 0.24^{c}$ & $46.77 \pm 0.36^{d}$ & 0.52 & 0.271 & 0.398 & 0.792 \\
\hline$A D F$ & $34.52 \pm 1.28^{\mathrm{e}}$ & $42.34 \pm 1.03^{\mathrm{a}}$ & $36.91 \pm 2.11^{d}$ & $38.22 \pm 0.68^{c}$ & $40.84 \pm 0.66^{b}$ & 0.61 & 0.259 & 0.957 & 0.199 \\
\hline$A D L$ & $13.66 \pm 0.64^{d}$ & $16.54 \pm 0.28^{\mathrm{a}}$ & $14.37 \pm 0.11^{c}$ & $15.06 \pm 0.36^{b}$ & $15.93 \pm 0.27^{b}$ & 0.17 & 0.936 & 0.096 & 0.735 \\
\hline $\mathrm{HC}$ & $20.02 \pm 0.25^{\mathrm{a}}$ & $2.93 \pm 0.33^{\mathrm{e}}$ & $18.65 \pm 0.32^{\mathrm{b}}$ & $10.82 \pm 0.88^{c}$ & $5.23 \pm 0.04^{\mathrm{d}}$ & 0.65 & 0.046 & 0.022 & 0.452 \\
\hline CEL & $25.04 \pm 0.14^{\mathrm{a}}$ & $25.18 \pm 0.22^{\mathrm{a}}$ & $25.06 \pm 0.25^{a}$ & $25.11 \pm 0.16^{\mathrm{a}}$ & $25.15 \pm 0.02^{\mathrm{a}}$ & 0.32 & 0.002 & $<0.001$ & 0.006 \\
\hline \multicolumn{10}{|c|}{ Apparent digestibility } \\
\hline DM (\%) & $66.33 \pm 1.32^{\mathrm{a}}$ & $45.05 \pm 0.77^{d}$ & $54.95 \pm 1.11^{\mathrm{b}}$ & $48.74 \pm 0.53^{c}$ & $49.61 \pm 0.24^{c}$ & 0.14 & 0.693 & 0.951 & 0.432 \\
\hline $\mathrm{OM}$ & $69.00 \pm 0.31^{\mathrm{a}}$ & $51.22 \pm 0.17^{\mathrm{e}}$ & $60.02 \pm 0.33^{b}$ & $53.35 \pm 0.25^{d}$ & $54.28 \pm 0.35^{c}$ & 2.00 & $<0.001$ & $<0.001$ & $<0.001$ \\
\hline $\mathrm{CP}$ & $41.63 \pm 0.26^{\mathrm{a}}$ & $32.98 \pm 0.34^{c}$ & $35.91 \pm 0.84^{\mathrm{b}}$ & $36.75 \pm 0.11^{b}$ & $42.19 \pm 1.20^{\mathrm{a}}$ & 0.25 & 0.547 & 0.923 & 0.422 \\
\hline NDF & $69.08 \pm 0.74^{\mathrm{a}}$ & $48.02 \pm 0.37^{d}$ & $56.11 \pm 0.25^{\mathrm{b}}$ & $51.25 \pm 0.22^{c}$ & $52.68 \pm 0.25^{c}$ & 0.03 & 0.004 & 0.025 & 0.063 \\
\hline ADF & $65.33 \pm 0.19^{a}$ & $53.43 \pm 0.19^{d}$ & $65.56 \pm 0.28^{a}$ & $59.59 \pm 0.48^{b}$ & $57.95 \pm 0.42^{c}$ & 0.21 & 0.522 & 0.837 & 0.441 \\
\hline$A D L$ & $22.13 \pm 1.33^{\mathrm{a}}$ & $7.56 \pm 0.22^{d}$ & $22.30 \pm 0.47^{a}$ & $12.52 \pm 0.25^{b}$ & $9.05 \pm 0.62^{c}$ & 0.74 & 0.003 & 0.021 & 0.056 \\
\hline $\mathrm{HC}$ & $75.54 \pm 0.15^{\mathrm{a}}$ & $27.10 \pm 0.92^{c}$ & $25.84 \pm 0.29^{d}$ & $28.68 \pm 0.83^{b}$ & $26.50 \pm 0.77^{d}$ & 0.05 & 0.007 & 0.069 & 0.065 \\
\hline CEL & $74.49 \pm 0.35^{\mathrm{d}}$ & $79.70 \pm 0.35^{c}$ & $83.81 \pm 0.26^{a}$ & $82.15 \pm 0.11^{b}$ & $81.55 \pm 0.26^{b}$ & 0.01 & 0.027 & 0.085 & 0.081 \\
\hline
\end{tabular}

Data are means of twelve sheep, means \pm SD within same columns with different superscript letters differ $(P<0.05)$. CS, corn stover; CA, caragana; MT 1, CS 80\% + CA 20\% MT 2, CS 50\% + CA 50\%; MT 3, CS 20\% + CA 80\%; DM, dry matter; OM, organic matter; $C P$, crude protein; NDF, neutral detergent fiber; $A D F$, acid detergent fiber; $A D L$, acid detergent lignin; HC, half cellulose; $C E L$, cellulose.

Table 4. Ruminal pH and contents of ammonia- $\mathrm{N}(\mathrm{m} \mathrm{mol} / \mathrm{L})$ and total VFA (\%) in Aerbasi cashmere goats fed corn stover (CS), caragana (CA) and their mixture (M)

\begin{tabular}{|c|c|c|c|c|c|c|c|c|c|}
\hline \multirow[t]{2}{*}{ Items } & \multirow[t]{2}{*}{ CS } & \multirow[t]{2}{*}{$\mathrm{CA}$} & \multirow[t]{2}{*}{ MT 1} & \multirow[t]{2}{*}{ MT 2} & \multirow[t]{2}{*}{ MT 3} & \multirow[t]{2}{*}{ SEM } & \multicolumn{3}{|c|}{$P$-value } \\
\hline & & & & & & & Linear & Linear & Linear \\
\hline $\mathrm{pH}$ & $6.65 \pm 0.04^{c}$ & $6.95 \pm 0.22^{\mathrm{a}}$ & $6.55 \pm 0.13^{d}$ & $6.69 \pm 0.23^{c}$ & $6.84 \pm 0.25^{\mathrm{b}}$ & 0.04 & 0.002 & 0.016 & 0.042 \\
\hline Ammonia-N & $2.28 \pm 0.21^{c}$ & $6.28 \pm 0.38^{\mathrm{a}}$ & $5.80 \pm 0.22^{b}$ & $5.59 \pm 0.25^{b}$ & $5.83 \pm 0.24^{\mathrm{b}}$ & 0.02 & $<0.001$ & $<0.001$ & $<0.001$ \\
\hline Acetic acid & $25.17 \pm 0.62^{d}$ & $29.32 \pm 1.02^{b}$ & $33.67 \pm 0.93^{a}$ & $28.33 \pm 0.24^{c}$ & $22.43 \pm 0.94^{\mathrm{e}}$ & 0.43 & 0.002 & 0.013 & 0.027 \\
\hline Propionic acid & $12.30 \pm 0.63^{b}$ & $13.15 \pm 0.35^{a}$ & $13.73 \pm 0.88^{a}$ & $12.79 \pm 0.25^{b}$ & $11.96 \pm 063^{c}$ & 0.06 & $<0.001$ & $<0.001$ & $<0.001$ \\
\hline Butyric acid & $7.41 \pm 0.22^{\mathrm{a}}$ & $5.72 \pm 0.29^{d}$ & $7.50 \pm 0.47^{a}$ & $6.99 \pm 0.44^{b}$ & $6.03 \pm 0.26^{c}$ & 0.01 & $<0.001$ & $<0.001$ & $<0.001$ \\
\hline Total VFA & $44.88 \pm 0.35^{c}$ & $48.19 \pm 0.25^{b}$ & $54.9 \pm 0.27^{a}$ & $48.11 \pm 0.22^{b}$ & $40.32 \pm 0.14^{d}$ & 0.04 & $<0.001$ & $<0.001$ & $<0.001$ \\
\hline $\mathrm{AA} / \mathrm{PA}$ & $2.05 \pm 0.82^{c}$ & $2.23 \pm 0.09^{b}$ & $2.45 \pm 0.33^{\mathrm{a}}$ & $2.22 \pm 0.24^{b}$ & $1.88 \pm 0.32^{\mathrm{d}}$ & 0.21 & 0.002 & 0.008 & 0.011 \\
\hline
\end{tabular}

Data are means of twelve sheep, means \pm SD within same columns with different superscript letters differ $(P<0.05)$. VFA, volatile fatty acid; AA/PA, ratio of acetic acid to propionic acid. CS, corn stover; CA, caragana; MT 1, CS $80 \%+C A 20 \% \square$ MT 2, CS 50\% + CA 50\%; MT 3, CS $20 \%+$ CA $80 \%$. 
Table 5. Particle size distribution of rumen in Aerbasi cashmere goats fed corn stover (CS), caragana (CA) and their mixture

\begin{tabular}{|c|c|c|c|c|c|c|c|c|c|}
\hline Particle size & CS & $\overline{C A}$ & MT 1 & MT 2 & MT 3 & \multirow[t]{2}{*}{ SEM } & \multicolumn{3}{|c|}{$P$-value } \\
\hline$(\mathrm{mm})$ & & & $(\%)$ & & & & Linear & Quadratic & Cubic \\
\hline$>5.0$ & $0.9 \pm 0.04^{\mathrm{a}}$ & $0.8 \pm 0.03^{a}$ & $0.51 \pm 0.02^{b}$ & $0.48 \pm 0.05^{b}$ & $0.45 \pm 0.07^{b}$ & 0.93 & 0.002 & 0.004 & 0.014 \\
\hline $1.0-5.0$ & $13.28 \pm 0.13^{\mathrm{a}}$ & $11.75 \pm 0.09^{b}$ & $11.45 \pm 0.08^{b}$ & $7.97 \pm 0.02^{c}$ & $5.12 \pm 0.11^{d}$ & 0.42 & 0.002 & 0.013 & 0.046 \\
\hline $0.5-1.0$ & $51.97 \pm 0.70^{d}$ & $54.02 \pm 0.22^{b}$ & $55.39 \pm 0.09^{a}$ & $53.99 \pm 0.18^{c}$ & $53.36 \pm 0.12^{c}$ & 1.37 & 0.410 & 0.520 & 0.050 \\
\hline $0.1-0.5$ & $32.05 \pm 0.62^{c}$ & $31.27 \pm 0.17^{d}$ & $31.06 \pm 0.41^{d}$ & $34.86 \pm 0.02^{b}$ & $37.65 \pm 0.53^{a}$ & 0.92 & 0.001 & 0.002 & 0.017 \\
\hline$\leq 0.1$ & $1.8 \pm 0.02^{d}$ & $2.16 \pm 0.03^{c}$ & $1.59 \pm 0.09^{e}$ & $2.7 \pm 0.02^{b}$ & $3.42 \pm 0.07^{a}$ & 0.13 & 0.423 & 0.771 & 0.396 \\
\hline
\end{tabular}

Data are means of twelve sheep, means \pm SD within same columns with different superscript letters differ $(P<0.05)$. CS, corn stover; CA, caragana; MT 1, CS $80 \%+$ CA 20\%םMT 2, CS 50\% + CA 50\%; MT 3, CS 20\% + CA $80 \%$.

\section{Supplementary Files}

This is a list of supplementary files associated with this preprint. Click to download.

- ArriveGuideline.docx 